\title{
Fate and transport of volatile organic compounds in glacial till and groundwater at an industrial site in Northern Ireland
}

\author{
D. H. Phillips $\cdot$ A. O. Thomas $\cdot$ K. Forde $\cdot$ K. Dickson $\cdot$ S. Plant $\cdot$ G. Norris $\cdot$ \\ B. Bone $\cdot$ R. M. Kalin
}

Received: 17 July 2006/ Accepted: 4 October 2006/Published online: 8 November 2006

(C) Springer-Verlag 2006

\begin{abstract}
Volatile organic compound (VOC) contamination of subsurface geological material and groundwater was discovered on the Nortel Monkstown industrial site, Belfast, Northern Ireland. The objectives of this study were to (1) investigate the characteristics of the geological material and its influences on contaminated groundwater flow across the site using borehole logs and hydrological evaluations, and (2) identify the contaminants and examine their distribution in the subsurface geological material and groundwater using chemical analysis. This report focuses on the eastern car park (ECP) which was a former storage area associated with trichloroethene (TCE) degreasing operations. This is where the greatest amount of volatile organic compounds (VOCs), particularly TCE, were detected. The
\end{abstract}

D. H. Phillips $(\bowtie) \cdot$ K. Dickson · R. M. Kalin

Environmental Engineering Research Centre,

School of Planning, Architecture and Civil Engineering,

Queen's University of Belfast, Belfast BT9 5AG,

Northern Ireland, UK

e-mail: d.phillips@qub.ac.uk

D. H. Phillips · B. Bone

Environment Agency, Contaminated Land Science Group,

Olton Court, 10 Warwick Road, Olton,

Solihull B92 7HX, England, UK

A. O. Thomas

ERM, Eaton House, North Hinksey Lane,

Oxford OX2 0QS, England, UK

K. Forde

URS Ireland Limited, Euro business Park,

Little Island, Cork, Ireland

S. Plant · G. Norris

Golder Associates (UK) Ltd., Landmere Lane,

Edwalton, Nottingham NG12 4DE, England, UK study site is on a complex deposit of clayey glacial till with discontinuous coarser grained lenses, mainly silts, sands and gravel, which occur at $0.45-7.82 \mathrm{~m}$ below ground level (bgl). The lenses overall form an elongated formation that acts as a small unconfined shallow aquifer. There is a continuous low permeable stiff clayey till layer beneath the lenses that performs as an aquitard to the groundwater. Highest concentrations of VOCs, mainly TCE, in the geological material and groundwater are in these coarser lenses at $\sim 4.5-7 \mathrm{~m}$ bgl. Highest TCE measurements at $390,000 \mu \mathrm{g} \mathrm{L}^{-1}$ for groundwater and at $39,000 \mu \mathrm{g} \mathrm{kg}^{-1}$ at $5.7 \mathrm{~m}$ for geological material were in borehole GA19 in the coarse lens zone. It is assumed that TCE gained entrance to the subsurface near this borehole where the clayey till was thin to absent above coarse lenses which provided little retardation to the vertical migration of this dense nonaqueous phase liquid (DNAPL) into the groundwater. However, TCE is present in low concentrations in the geological material overlying the coarse lens zone. Additionally, VOCs appear to be associated with poorly drained layers and in peat $<3.0 \mathrm{~m} \mathrm{bgl}$ in the ECP. Some indication of natural attenuation as VOCs degradation products vinyl chloride (VC) and dichloromethane (DCM) also occur on the site.

Keywords Trichloroethene Glacial till .

Groundwater · Volatile organic compounds · Dense non-aqueous phase liquid · Aquifer - Aquitard

\section{Introduction}

The activities on industrial sites frequently lead to the contamination of their subsurface geological material 
and groundwater with harmful volatile organic compounds (VOCs) (Broster and Pupek 2001; An et al. 2004; Parker et al. 2004). Understanding the fate and transport of these contaminants is needed to determine preliminary cost estimates for clean-up and plans of action for remedial measures (Morrissey et al. 1999). The Monkstown site in Northern Ireland has been in operation since 1962 in the manufacture and assembly of electronic equipment and was purchased by Nortel Networks in the early 1990s. Subsurface geological material, composed mainly of clayey glacial till, and groundwater were discovered to be contaminated with VOCs, mainly trichloroethene (TCE), during due diligence environmental investigations. TCE is a category 3 carcinogen in the European Union Dangerous Substance Directive (European Commission 1999).

Erratic heterogeneous glacial till underlying the site poses many problems in interpreting the geology and hydrogeology and, more importantly, complicates the migration of TCE contaminated groundwater. The highly toxic TCE is a dense non-aqueous phase liquid (DNAPL) that has low solubility, high interfacial tension, and a tendency to sink below the water table (Zhang et al. 2003). Because of these properties, the behaviour of TCE in the natural environment is difficult to predict (Barbee 1994; Oostrom et al. 1999) particularly in heterogeneous material (Zhang et al. 2003). Gravity has a greater influence on DNAPL movement compared to natural groundwater flow (Barbee 1994). DNAPLs usually migrate vertically and achieve a static spatial distribution in pools or lenses within the sediments, which are difficult to locate. For example, Oostrom et al. (1999) report the downward migration of TCE in sands as narrow 3-8 mm fingers. Therefore, these pools can act as long-term subsurface sources of dissolved phase contamination (Barbee 1994; Oostrom et al. 1999; Bradford et al. 2003). The variability of the glacial sediments in Monkstown is likely to enhance the already unpredictable behavior of TCE DNAPL and effect contaminant transport.

Nortel Networks undertook a voluntary cleanup of the site which involved partial excavation and landfilling of contaminated soil and the installation of a zero valent iron permeable reactive barrier (PRB). The PRB was installed to treat the shallow ground water in an area of the site known as the eastern car park (ECP) to prevent off site migration to downgradient land. This research was part of a preliminary study carriedout on the site to characterize and determine the extent of the contaminants in the subsurface geological material and groundwater in order to evaluate the need for remedial measures and determine preliminary cost estimates for implementing remediation activities.
The objectives of this study were to (1) investigate the characteristics of the geological material and its influences on contaminated groundwater flow across the site using borehole logs and hydrological evaluations, and (2) identify the contaminants and examine their distribution in the subsurface geological material and groundwater using chemical analysis.

\section{Materials and methods}

\section{Study site history}

The Nortel Network Facility, which occupies about $15 \mathrm{ha}$, is in the industrial area of Monkstown, Newtownabbey in the northeast corner of Belfast, Northern Ireland (Fig. 1). From 1962 to 1985, the Monkstown site was involved with the manufacturing of printed circuit boards and assembly of electromechanical switching equipment. In 1985 the plant began manufacturing telephones, fax machines, switching stations, and assorted electrical equipment. In the early 1990s Nortel Network, a multinational telecommunication company, that develops and manufactures telecommunication components, purchased the site. The site is surrounded by residential properties to the south and west and industry to the north and east. Buildings and parking lots cover most of the subject site and form a low permeability cover. There is a $3 \mathrm{~m}$ elevation difference at the site with elevation decreasing from west to east with runoff moving through drains and an oil/ water separator before discharging into a local stream. A number of past activities could have been responsible for the subsurface contamination at the site (Beck et al. 2001).

Borehole installation and sampling of geological material

Two light cable percussive rigs were used to construct a series of 21 boreholes to the depths of 7-18.5 m across the site (Fig. 2) using the clean drilling technique in order to limit the possibility of cross contamination between boreholes. During drilling no water was added to lubricate the drilling process. The rig casing tools and any other item used for drilling and sampling were steam cleaned prior to mobilization onto each borehole location. The steam cleaning was carried-out on a specially designated area of hardstanding at a distance from any of the drilling sites. No oil was added to any of the drilling equipment unless absolutely necessary, in which cases a little vegetable oil was used. The water used in the steam cleaner was obtained from a potable 
Fig. 1 Location of the study site in Northern Ireland

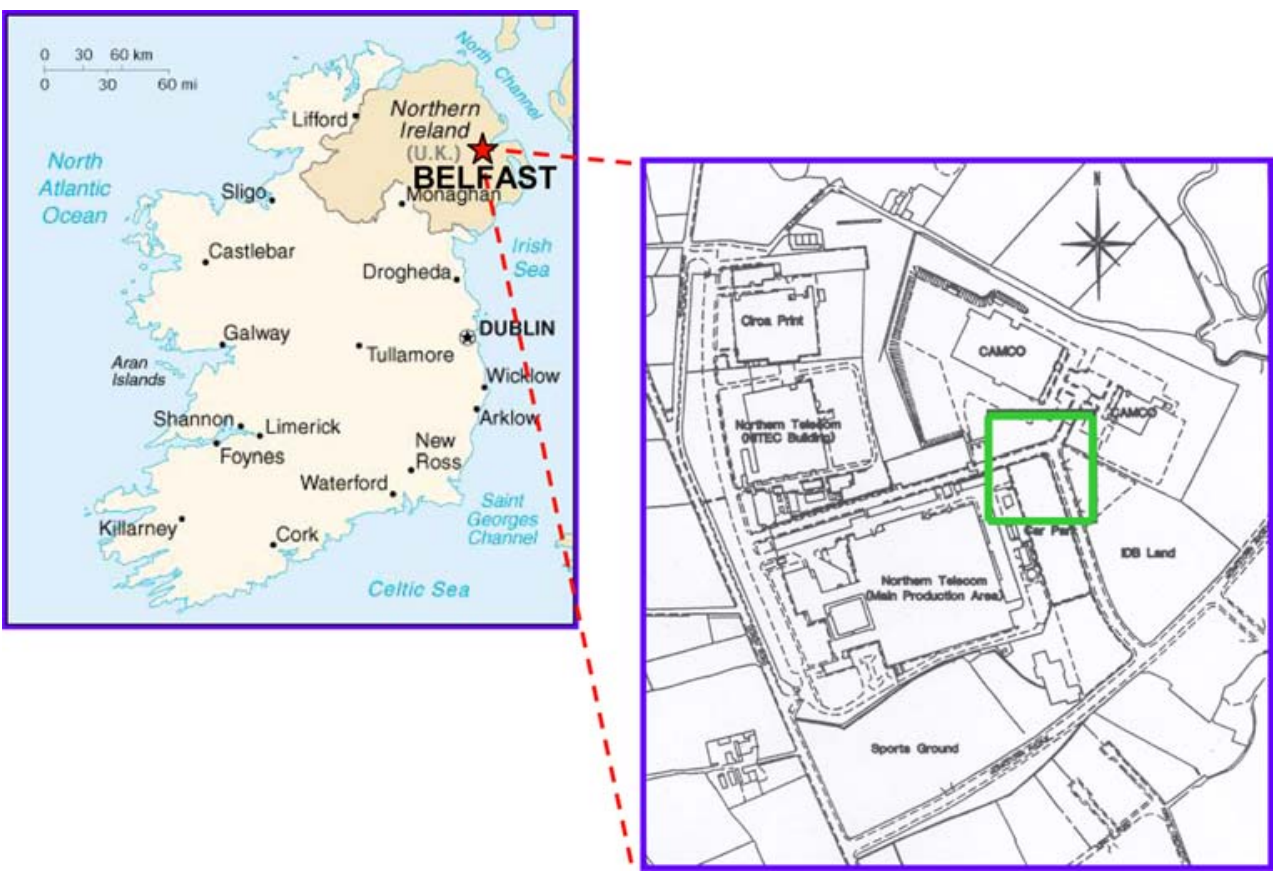

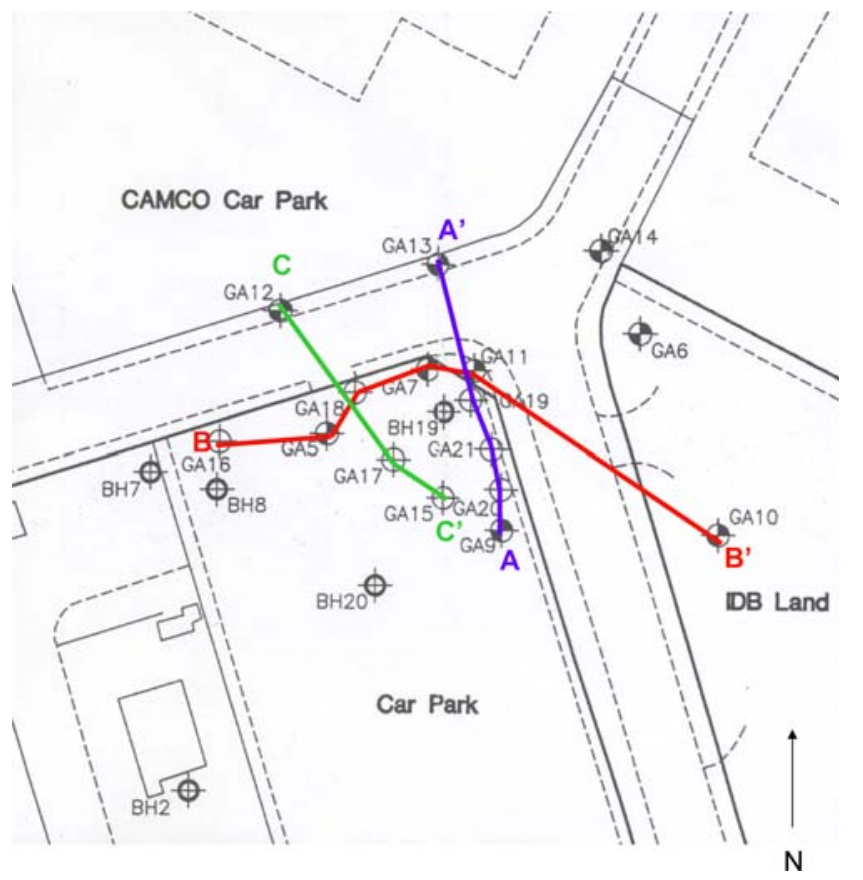

Fig. 2 Location of the various boreholes in the study and the cross sections of boreholes shown in Fig. 3

water source. A non-phosphate detergent was added to the water during cleaning before rinsing in potable water. The wash water was collected in a lined sump and screened with a calibrated portable Foxboro organic vapor analyzer (OVA) 128 flame ionization detector (FID) (Foxboro, MA, USA) prior to discharge.
The cores were described and geological material was sampled at $1 \mathrm{~m}$ intervals using clean gloves. VOCs in the samples were measured in the field using the calibrated FID. Precleaned 11 glass jars were filled to about half capacity, sealed and allowed to equilibrate over time. The FID probe was then inserted into the jar through a rubber bung in the lid and the VOC content of the headspace was determined according to the scale of deflection on the FID. Samples showing higher than average levels of organic vapor were analyzed using a Foxboro OVA 128 gas chromatograph (GC) (Foxboro, MA, USA) to determine which individual compounds were present through a comparison of peak retention times with VOC standards (USEPA 2003). Samples selected for laboratory VOC quantification were transferred to a clean sample jar immediately and were stored at between 0 and $4^{\circ} \mathrm{C}$ prior to analysis. All the sample bottles were filled to their maximum capacity in order to exclude air. Falling head test using the Hvorslev (1951) method was used to determine permeability of the geological material.

Piezometer installation and groundwater sampling

A piezometer consisting of a $50 \mathrm{~mm}$ internal diameter high density polyethylene (HDPE) pipe was installed to the base of each borehole. The bottom $3 \mathrm{~m}$ was slotted screen wrapped in a polypropylene geotextile filter and the remainder of the pipe was plain. The pipe was sealed at the top by a plastic cap with an ' $O$ ' ring seal. The screen was surrounded by a gravel filter pack 
which was sealed at the top with a $1 \mathrm{~m}$ bentonite plug. The remainder of the borehole was filled to $1 \mathrm{~m}$ below the surface with a cement/bentonite grout. The top $1 \mathrm{~m}$ of the borehole was completed using concrete and a stopcock cover was cemented into place at the surface to allow access. A dedicated water sampling system was installed in each borehole, consisting of a $25 \mathrm{~mm}$ Teflon foot valve connected to a $21 \mathrm{~mm}$ internal diameter polyethylene tube.

Two boreholes were completed with multi-level piezometers to monitor vertical differences in groundwater pressure and chemistry. GA19 was completed with a nest of two $50 \mathrm{~mm}$ HDPE piezometers constructed and sealed in a manner similar to the single piezometers. GA20 was completed with two ceramic Casagrande type piezometers set in sand filters, sealed with bentonite and connected to $20 \mathrm{~mm}$ HDPE piezometer tubing.

Surface waters were sampled from a brook at Kings Court about $250 \mathrm{~m}$ southwest of the ECP for VOC analysis. The samples were collected from midstream. Sampling containers were mixed twice with the stream water before filling.

Prior to sampling, all boreholes were purged in which a volume of water equal to three times the volume of water present within the filter pack and the piezometer was removed. In most boreholes, this purging was achieved over a period of several days, as many holes were pumped temporarily dry after about one volume had been removed. In certain boreholes, sampling occurred as soon as sufficient water had recharged to the borehole to provide the volume necessary for sampling requirements. This was considered satisfactory, as no drilling fluid was added to the boreholes during the drilling. VOCs in the groundwater samples were analyzed by purge and trap GC MS. Major cations $\left(\mathrm{Ca}^{2+}, \mathrm{Mg}^{2+}, \mathrm{K}^{+}\right.$, and $\left.\mathrm{Na}^{+}\right)$were measured by inductively coupled plasma atomic emission spectroscopy (ICP-AES). Anions $\left(\mathrm{Cl}^{-}, \mathrm{SO}_{4}^{2-}\right)$ were measured by high performance liquid chromatography-ion chromatography (HPLC-IC) analysis and $\mathrm{HCO}_{3}^{-}$was measured by the titration methods for the analysis of water (MEWAM 1980). Blanks and three duplicate samples were run for QA/QC.

\section{Results and discussion}

\section{Glacial till}

The surface of the study site is covered with a variety of materials. These materials consist of a 0.1-1.1 m zone of disturbed soil material (GA2, GA4), GA3-peat (background area), GA8-peat, BH16-peat, made ashy ground (GA6, GA10), compact fill of dolerite cobbles, pebbles, gravel and sand or a pavement. The peat in GA3 contains visible organic matter and freshwater shells which indicate a past pond environment in a low lying hollow in the surface of the till that was eventually filled. Below these surface layers, soft clays were present in several boreholes (GA3, GA6, GA8, GA9, GA10 and GA14) and varied greatly in thickness (0$3.2 \mathrm{~m}$ ) and overlaid coarse and clayey glacial till. These clays range in color as a result of a variety of oxidation states, such as grey, greyish green, and black (organic rich) which indicate reduced conditions or water logging (USDA 2003), yellowish brown and orange brown which indicate greater oxidized conditions (USDA 2003) or may be banded, as in GA8.

The clays grade into a less weathered, more compacted clayey glacial deposit of the Late Pleistocene Age (13,000-17,000 BP) (McCabe and Cofaigh 1994). The deposit is in the form of a complex succession of stiff, red-brown clayey till, with varying amounts of poorly sorted and unstratified silts, sands, subrounded and angular gravel, pebbles and surrounded (mainly broken) cobbles. The coarser materials form discrete, discontinuous lenses of sand, silty sands and gravel that do not appear to represent a continuous, laterally extensive layer underlying the site. Similar glacial deposits are reported as till with silty and sandy lenses in Saskatchewan, Canada (Shaw and Hendry 1998), glacial deposits with glaciofuvial sand and gravel layers in Ringe, Denmark (Broster and Pupek 2001), till with sand and gravel layers in New Brunswick Canada (Meriano and Eyles 2003).

At the study site, many coarser lenses that occur at the depths of between 6 and $7 \mathrm{~m} \mathrm{bgl}$ in boreholes, such as in GA7, GA10, GA11, GA12, and GA13, but are not seen in GA8, GA9 or GA14 (Fig. 3). Also, the sand layer at about $2 \mathrm{~m} \mathrm{bgl}$ in GA5, GA7 and GA11 does not occur in nearby boreholes, while $\mathrm{BH} 21$ penetrate sands and gravels that may represent other lenses. Lenses of clay dominated material are observed in GA7, GA11, GA6 and GA21 that vary in thickness from $0.2 \mathrm{~m}$ (GA21) to $3.4 \mathrm{~m}$ (GA6). These coarse and clayey lenses within the massive clay till represent sediments carried by melt water streams on or within the glacier (Knight 2003). The depth of these coarser deposits in the northeast corner of the car park varies between 5 and $10 \mathrm{~m} \mathrm{bgl} \mathrm{(though} \mathrm{their} \mathrm{base} \mathrm{was} \mathrm{not}$ determined in GA6, GA11, or GA13) and their thickness varies from $1.9 \mathrm{~m}$ (GA5) to $9 \mathrm{~m}$ (GA19). The maximum extent of these lenses is illustrated in GA16, GA9, BH18, and BH20, which only penetrate clay till beneath made ground. The north and east boundaries 
Fig. 3 Cross sections of boreholes across the study site showing the distribution of glacial till, lithology and total VOCs $\left(\mathrm{mg} \mathrm{kg}^{-1}\right)$.

Depths $(\mathrm{m})$ are shown on the left side of the logs [notehighest VOCs $\left(>40 \mathrm{mg} \mathrm{kg}^{-1}\right)$ are noted in the graph]

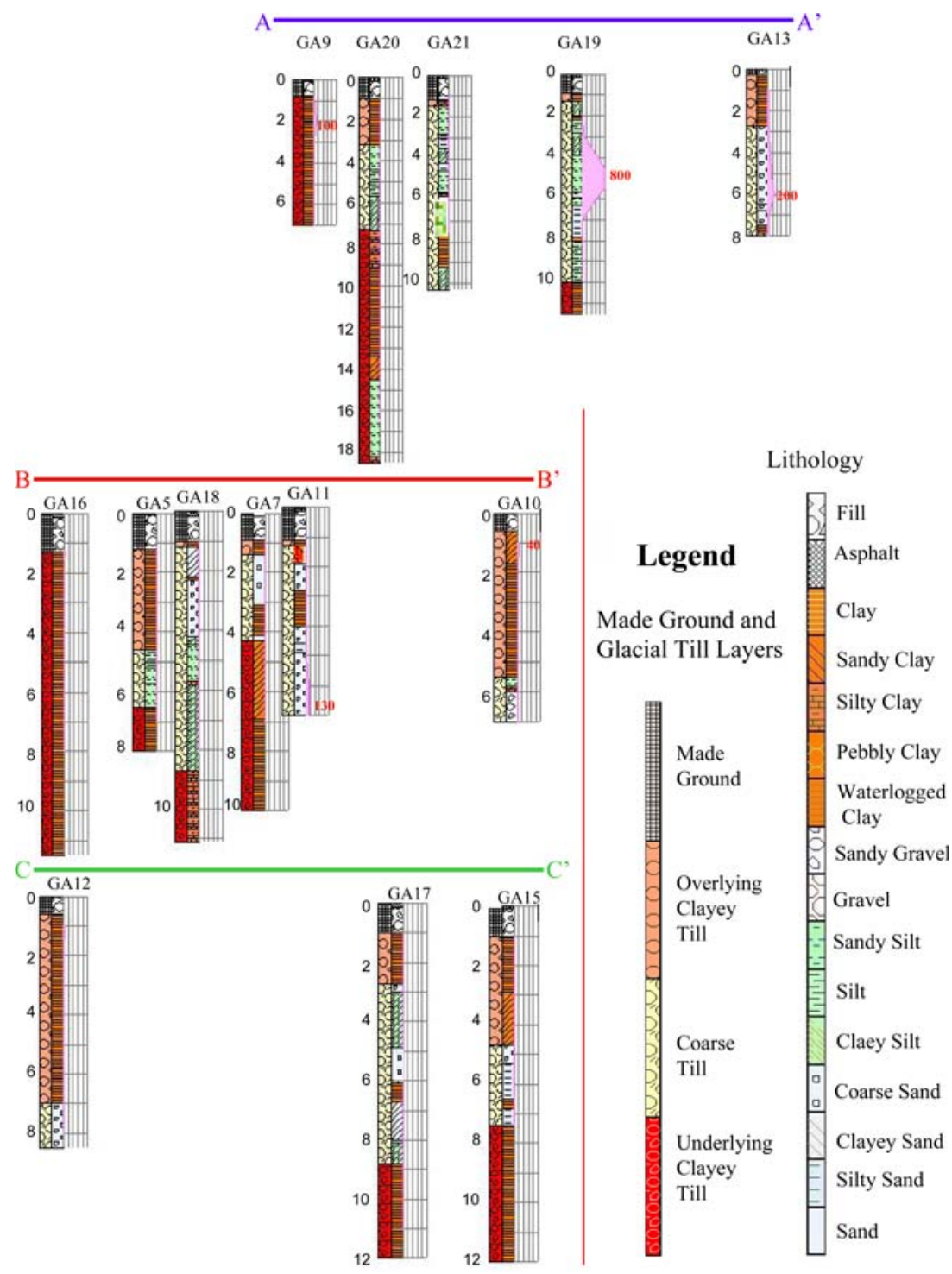

of the coarser material are less well defined, although GA14 may represent the greatest extent to the northeast. Coarse till lenses are absent from GA14 and the stiff, red-brown clayey till directly underlies the made ground at $0.75 \mathrm{~m}$. GA12, GA13, GA6 and GA10 do not penetrate the entire thickness of the coarser material. Borehole logs plotted using Rockware (2004) show that these coarser materials form an elongated formation with its axis running northwest to southeast and is surrounded by clay till to the southwest (GA9, GA16, BH8, and BH20) and northeast (GA14) (Fig. 3).

A continuous layer of thick, stiff clay till underlies the coarse lenses in all boreholes at about $10 \mathrm{~m} \mathrm{bgl}$ across the ECP area (Fig. 4). The clay layer thickness ranges from 1.5 to $>7 \mathrm{~m}$ with no visible fractures. This massive clay deposit acts as a barrier/aquitard or retardant to downward migration of chlorinated solvents. Parker et al. (2004) report minimal TCE diffusion into a similar silty clay aquitard 35-40 years after an aqueous phase TCE spill at an industrial site. The 3D geometry of the surface of the clay deposit at the site created from the borehole logs indicates that the till forms a dip or 'cup-like' structure with its lowest point centered on GA19 (Fig. 4). The presence and angle of this surface may direct any TCE DNAPL in a northeast direction towards the site. A deeper horizon of stiff silt, at least $4 \mathrm{~m}$ thick, occurs in GA20 and appears to be hydraulically separate from the other layers, usually found between about 4-8 $\mathrm{m}$ thick deep. Its extent and orientation are unknown. 
Fig. 4 Modelled crosssections of the stratigraphy across the site showing the distribution of the different layers of glacial till

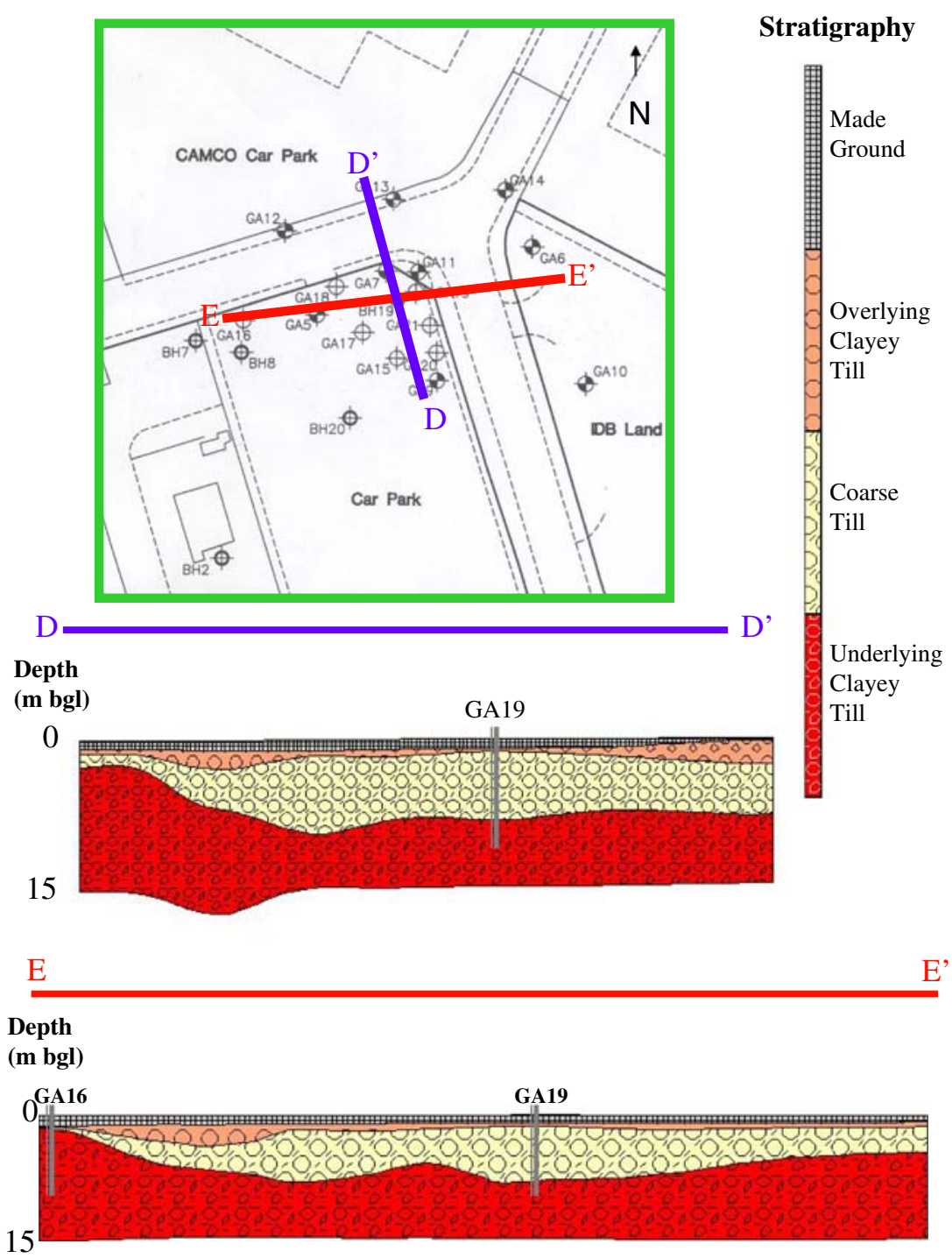

\section{Hydrogeology}

The intercalated and discontinuous coarser lenses create a complex, shallow, unconfined aquifer system where water tables occur at depths ranging from 0.45 to $7.82 \mathrm{~m}$. Similar aquifer systems in coarser layers and lens in glacial till are reported by Nilsson et al. (2001), Broster and Pupek (2001) and Meriano and Eyles (2003). The water levels in GA6 and GA10 are about 0.8 m lower than GA11, GA12 and GA13, which may indicate that GA6 and GA10 penetrate a different lens. GA 9 and GA 14 are all completed in the clay till and appear to show a gradient toward the northeast of the till. Generally, the shallow groundwater flow in the vicinity of the ECP is in an east to northeast direction. The clay material overlying these shallow coarse lenses and the fill material in the ECP varies greatly in thickness. It is thin, and, in places non-existent, in the northeast corner of the ECP (Fig. 4). This clay layer probably acts as a less effective barrier to solvent penetration and water infiltration. The underlying bedrock consists of Mercia Mudstone Group (Geological Survey of Northern Ireland 1997).

In the northeast corner of the ECP, the hydraulic heads are in the range of 30.2-30.5 $\mathrm{m}$ AOD and decline to $\sim 29.95 \mathrm{~m}$ AOD to the north (GA12, GA13) and to $\sim 29.50 \mathrm{~m} \mathrm{AOD}$ to the east (GA6, GA10) (Fig. 5). A distinct groundwater 'mound' is present in the northeast corner of the ECP with heads of about $30.45 \mathrm{~m}$ AOD near GA19, GA7 and GA11 and lower heads on all sides, implying radial flow away from the 'mound'. This groundwater 'mound' is associated with the area of thin, sometimes non existent, clay cover (Fig. 4) and may be due to increased infiltration of rainwater as the annual precipitation is about 1,0001,200 $\mathrm{mm}$ (Robins 1994). The base of the hardcore fill 
Fig. 5 Contour map of the groundwater levels across the ECP showing the groundwater mound

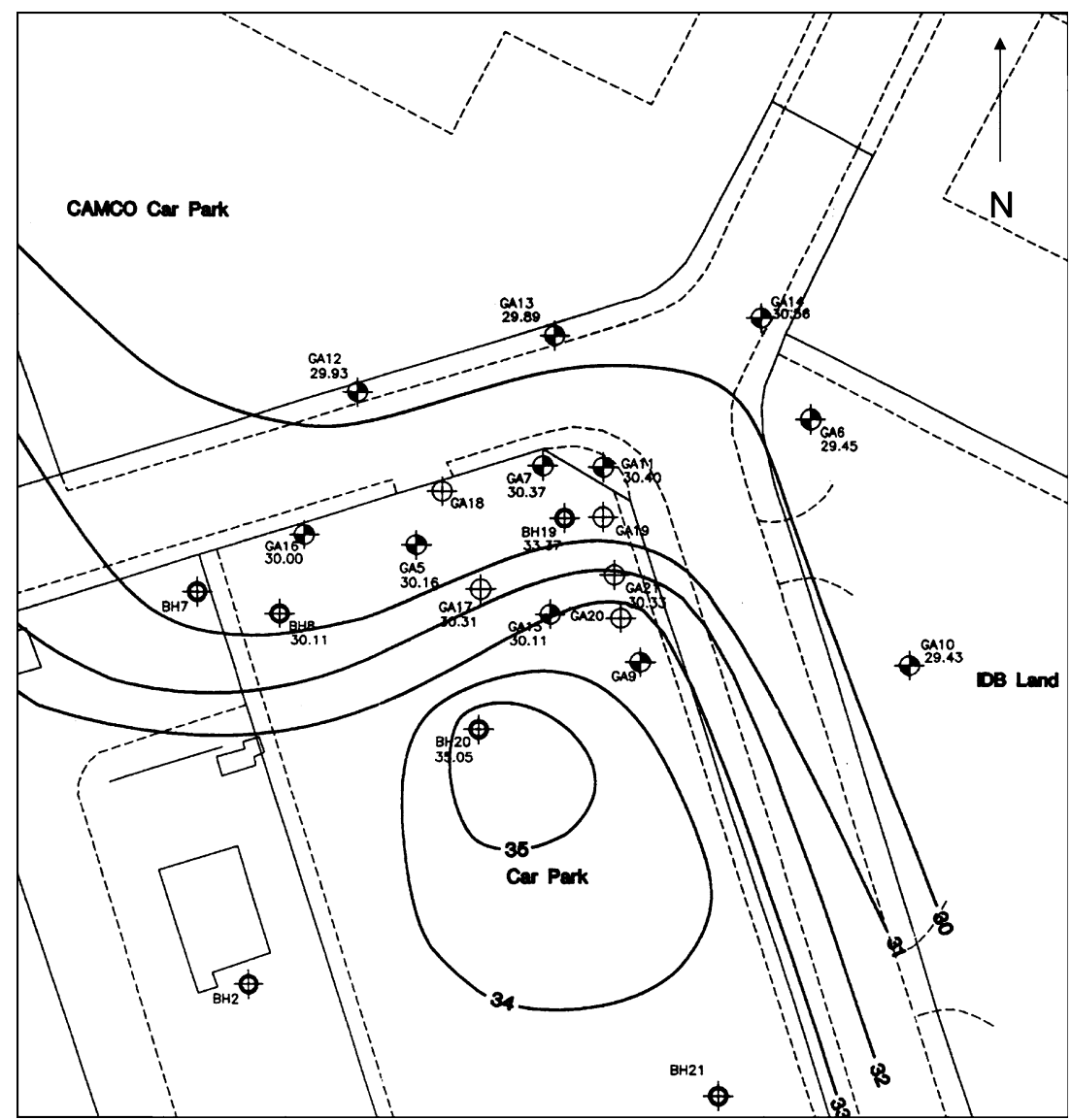

underlying the asphalt of the car park and overlying the clay cover was found to be saturated in several boreholes and this water may act as a source of recharge. High heads (between $\sim 31 \mathrm{~m}$ AOD and $35 \mathrm{~m}$ AOD) are found in boreholes to the south and west of BH19 and correspond to areas of clay till identified in borehole logs and falling head tests. These heads appear to have a wide spatial variability (i.e. a $2 \mathrm{~m}$ head difference between GH20 and GA9, and the anomalously high water levels in $\mathrm{BH} 20$ ) and this may be due to the low permeability and heterogeneous composition of this clayey material. The contoured map in Fig. 5 shows the steepest gradients (0.023-0.03) are towards the north (GA12, GA13) and east (GA6, GA10) and this indicates that the majority of the flow is in these directions (i.e. off site). Gradients to the southwest of GA19 are about 0.01. Borehole GA20 contains two piezometers installed at different depths, GA20A is installed from 6.7 to $7.0 \mathrm{~m}$ and GA20B is installed from 14.7 to $15 \mathrm{~m}$. The water levels are $30.74 \mathrm{~m}$ AOD in the deeper piezometer and $30.37 \mathrm{~m}$ AOD in the shallower piezometer, while the calculated hydraulic gradient is -0.09 . Although the presence of the groundwater 'mound' in the ECP implies that flow may occur south and west of the BH19 area, water is unlikely to move far in these directions due to the presence of the high heads in the thick, low permeability clayey till which probably acts as a hydraulic barrier/aquitard to water flow and dissolved phase contaminant migration.

The falling head permeability tests show that an area of relatively high permeability exists in the north eastern corner of the ECP (Fig. 6). The permeability distribution corresponds to the shape of the lens of coarser sediments, as determined by the borehole logs and also confirms the presence of low permeability clayey material to the south and west of the BH19 area. There is a two to three orders of magnitude difference in permeability between the lens of coarser material $\left(10^{-5}\right.$ to $\left.10^{-7} \mathrm{~m} / \mathrm{s}\right)$ and the clay dominated till $\left(<10^{-9}\right.$ $\mathrm{m} / \mathrm{s}$ ) bordering it to the south and west. Low permeable clay till is common. Similarly, Shaw and Hendy (1998) report the permeability of clay till in Saskatchewan Canada at $10^{-11}$ to $10^{-12} \mathrm{~m} / \mathrm{s}$. This difference in permeability on the site is probably responsible for the abrupt $3 \mathrm{~m}$ drop in head along the margins of the coarse lens, as the silts and sands enables the groundwater to drain more rapidly and easily than the low permeability clay till. Due to the head difference between the clay till and the sands and silts, groundwater 
Fig. 6 Contour map of the distribution of the permeabilities in the ECP

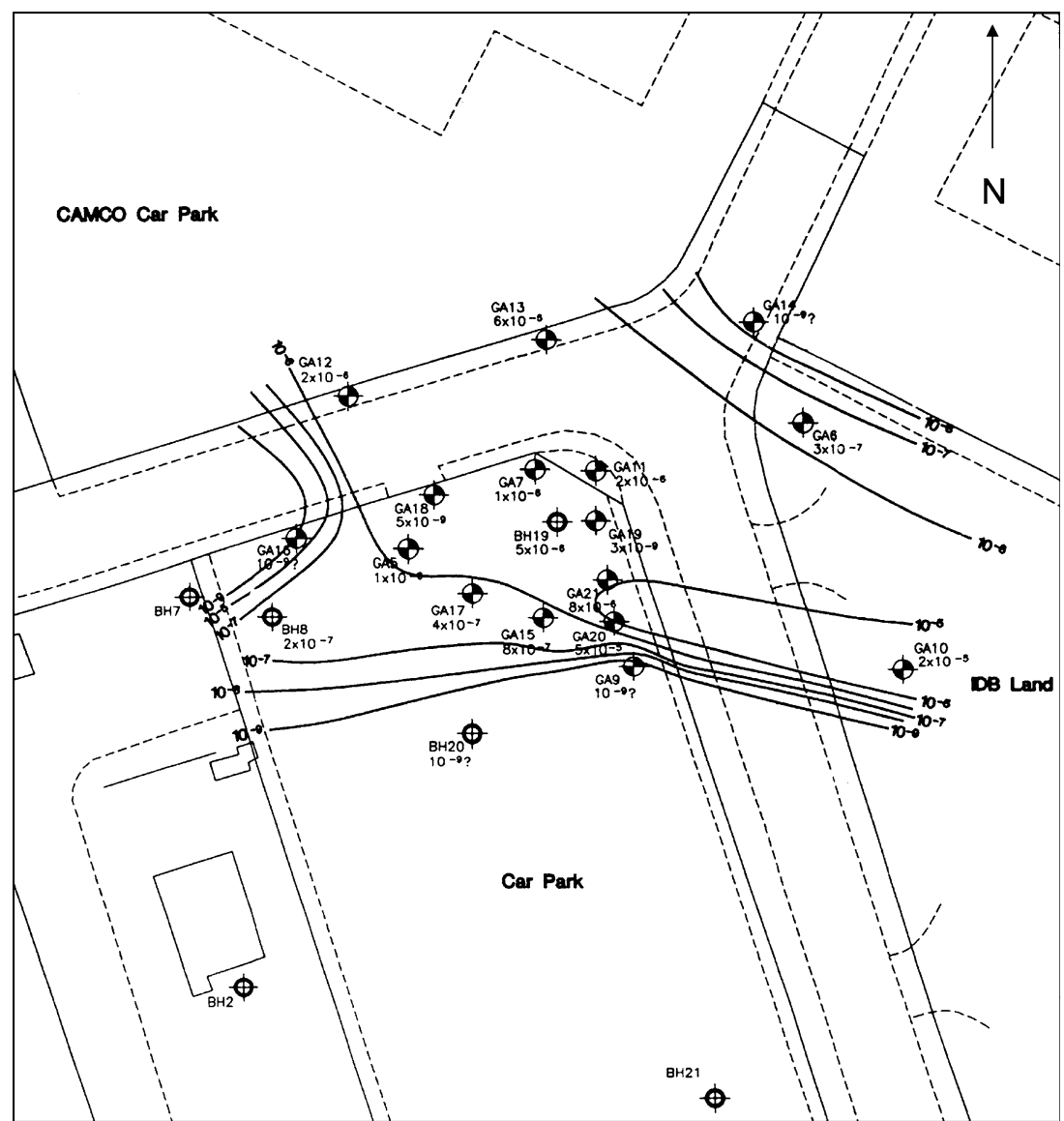

is likely to flow from the till into the sand lenses, although this flow rate is likely to be low, given the low permeability of the clay till.

Contaminant distribution in glacial till and groundwater

\section{VOCs in glacial till}

TCE, MEK, acetone and the degradation product DCM are the most abundant solvents detected in the geological material (Table 1). However, MEK and acetone were detected in blanks, therefore the concentrations in the samples could be at least partially due to laboratory artifacts. The highest VOC levels, particularly TCE, in the glacial till are associated with the coarser, more permeable layers, such as silty sands and sand and gravel lenses, and indicate that these contaminants have settled in these lenses (Table 2). Similar occurrences are reported by Broster and Pupek (2001) where PCE was discovered in aquifers in coarse grained glaciofluvial sands and gravel layers. In most boreholes on the ECP, field organic vapor concentrations peaked at about $6 \mathrm{~m}$ where many of the coarser lenses occur (Fig. 4; Table 1). In GA19, laboratory measured TCE concentrations decline from $39,000 \mu \mathrm{g} \mathrm{kg}^{-1}$ at $5.7 \mathrm{~m}$ to $320 \mu \mathrm{g} \mathrm{kg}^{-1}$ at $7.7 \mathrm{~m} \mathrm{bgl}$ and is below the detection limit at $12 \mathrm{~m}$ bgl. GA16 penetrates only the clayey till, and has low levels of VOCs $\left(<1.5 \mathrm{mg} \mathrm{kg}^{-1}\right)$ with the exception of the sample from the top of the clay till at $1.3 \mathrm{~m} \mathrm{bgl}\left(15 \mathrm{mg} \mathrm{kg}^{-1}\right)$. However, this may be due to the petroleum hydrocarbon contaminated water in the fill material overlying the till. The clay till at the ECP, appears to be uncontaminated at depth, as samples from $12 \mathrm{~m} \mathrm{bgl} \mathrm{in}$ GA 19 and $10 \mathrm{~m}$ bgl GA20 show TCE levels of less than $1 \mathrm{mg} \mathrm{kg}^{-1}$. Additionally, a sample from $16.6 \mathrm{~m}$ in GA20 (i.e. the deeper coarse lens, below the $7 \mathrm{~m} \mathrm{bgl}$ clay layer) contains no TCE. This suggests that VOC transport occurs predominantly in the coarse horizons. However, transport through the clay till may occur through the water bearing fractures and contamination in the till may consequently be restricted to these fractures. Parker et al. $(1997,2004)$ report that the length of time for the detection of DNAPL in fractures are shorter relative to the ages of the subsurface contamination of DNAPL at many industrial sites. This may cause many DNAPL source zones, such as 


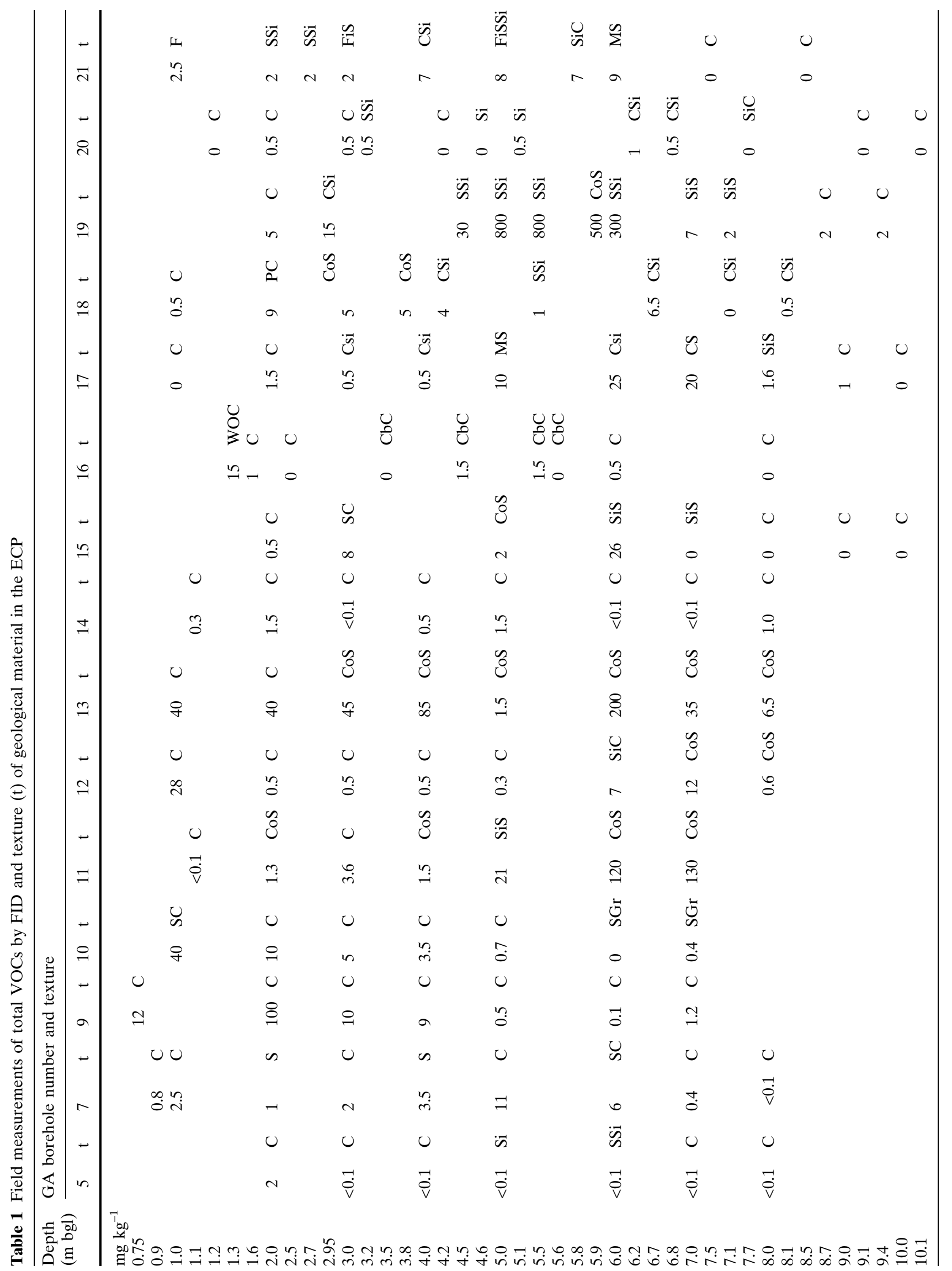




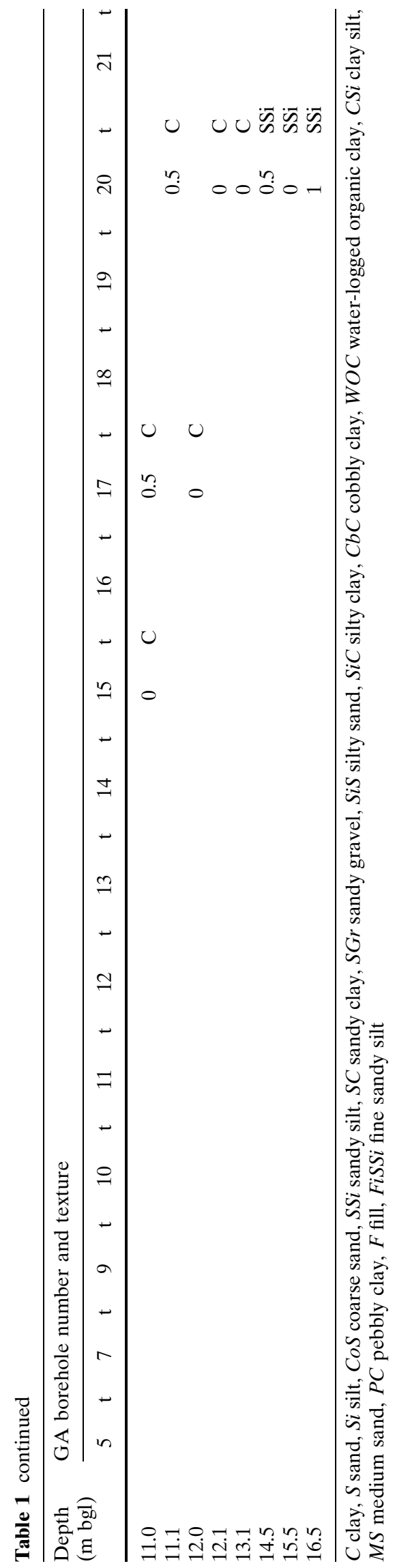

preferential flow pathways in the form of cracks, fine fractures and channels of biological origin, to have small or no detectible DNAPL phase. However, the matrix may retain contaminants longer and act as a long-term source. Rapid DNAPL flow is reported to occur under a $30 \mathrm{~cm}$ head through $17 \mu \mathrm{m}$ thick fractures due to the high density, low viscosity of the material (Parker et al. 2004). Other VOCs present include butanone and acetone, particularly at $5 \mathrm{~m}$ depth in GA7.

\section{VOCs in groundwater}

TCE is the major groundwater contaminant at the ECP site (Table 3). Former storage of drums and frames from the TCE degreaser in the ECP area are likely sources of the TCE, although the made ground examined in this investigation appears to be relatively free of contamination, as does the underlying clay till. An area of residual contamination would be expected at the interface between the clay till and the made ground, if there were vertical movements of TCE. Although, locations where the groundwater became contaminated are unclear, results indicate that the source is likely to be in the region of GA19, GA20 and GA11. As DNAPL movement is predominantly downward, it is likely that the TCE spill occurred in the area near these boreholes and that downward movement of the contaminants occurred through the fissures in the till, as the till itself appears to be relatively uncontaminated geological material as similarly described by Parker et al. (2004). Headspace and laboratory analyses of samples from GA19 indicate that the TCE was concentrated in a discrete band of coarse sand between 5.6 and $5.9 \mathrm{~m}$ and the residual concentrations in the overlying silt are less than expected had the TCE soaked through this area (Fig. 4; Tables 1, 2). Therefore, the TCE gained access to this sand lens through a discrete natural or anthropogenic pathway(s) which has not been identified. High levels of butanone and acetone were also found in those water samples which had high TCE levels see earlier.

The distribution of dissolved TCE is dependent upon the prevailing groundwater flow and the orientation of the coarser more permeable material which runs northwest to southwest across the northeast corner of the ECP. TCE concentrations decline by only one order of magnitude northwards (GA13), suggesting that a plume of dissolved contaminants is moving northward from the source area, in the direction of the steep groundwater gradient identified from the piezometric data. According to VOC measurements of 


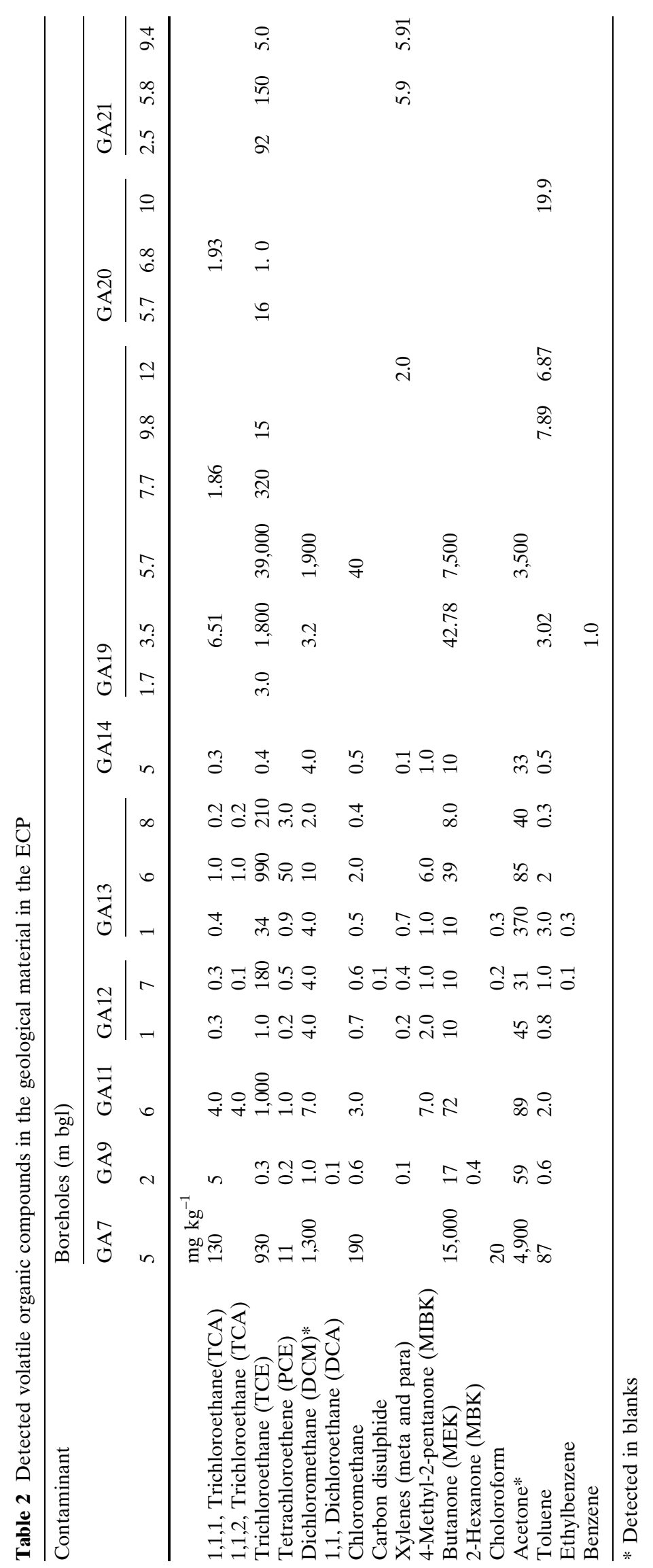


Table 3 Detected volatile organic compounds in groundwater

\begin{tabular}{llllllllllllllll}
\hline 5 & 7 & 9 & 10 & 11 & 12 & 13 & 15 & 16 & 17 & $18 \mathrm{~B}$ & $19 \mathrm{~A}$ & $19 \mathrm{~B}$ & $20 \mathrm{~A}$ & $20 \mathrm{~B}$ & 21
\end{tabular}

ug $\mathrm{L}^{-1}$

$1,1,1$, Trichloroethane

(TCA)

1,1,2, Trichloroethane (TCA)

Trichloroethane (TCE)

Tetrachloroethene (PCE)

1,1 Dichloroethane (DCA)

Vnyl Chloride

Trans-1,2-

dichloroethene

(DCE)

Chloromethane

Dibromochloromethane

Bromodichloromethane

Carbon disulphide

4-Methyl-2-Pentanone

(MIBK)

Butanone (MEK)

2-Hexanone (MDK)

Acetone

Chloroform

Benzene

Toluene

Ethylbenzene

Xylenes

(meta and para)

Contaminant

$17 \quad 160$

150

0.2

3.0

0.1

$\begin{array}{lll}220 & 270 \quad 6.0\end{array}$

120

$2,100 \quad 0.3 \quad 50$

$\begin{array}{llllll}1,200 & 85 & 33 & 1,600 & 150 & 33\end{array}$

22

7.0

68

5.0
2.0
1.86

82
500

56

490

93

$8.0 \quad 4,100$

7,500

$\begin{array}{lll}33-150 & 150\end{array}$

4.2

6.87

789

4,966

2.0

$\begin{array}{llll}99 & 10 & 87 & 4.2 \\ & 44\end{array}$

550

26238

$2.0 \quad 48$

3.0

\begin{tabular}{llllllllllllll}
\cline { 2 - 9 } & 1 & 6 & 7 & 8 & 14 & 17 & 18 & 19 & $20 \mathrm{~A}$ & $20 \mathrm{~B}$ & 21 & \\
\hline
\end{tabular}

$1,1,1$, Trichloroethane (TCA)

$1,1,2$, Trichloroethane (TCA)

Trichloroethane (TCE)

Tetrachloroethene (PCE)

1,1 Dichloroethane (DCA)

Vinyl Chloride

Trans-1, 2-dichloroethene (DCE)

Chloromethane ug $\mathrm{L}^{-1}$

Carbon disulphide

4-Methyl-2-Pentanone (MIBK)

Butanone (MEK)

2-Hexanone (MBK)

Acetone

Chloroform

Benzene

Toluene

Ethylbenzene

Xylenes (meta and para)

Chloroeththane

1,2-Dichloroethane

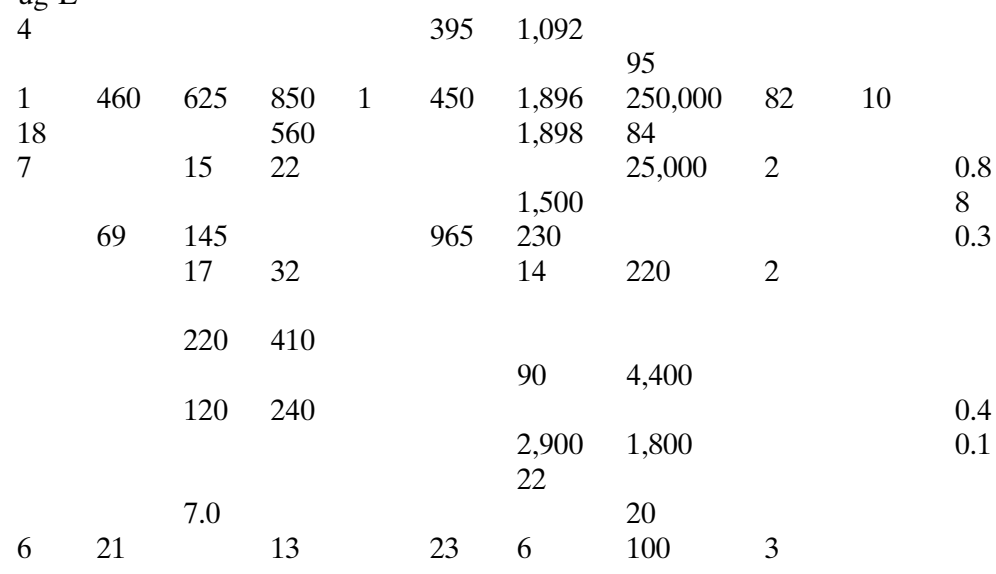

0.1 
Fig. 7 Piper diagram of the groundwaters from the boreholes in the ECP

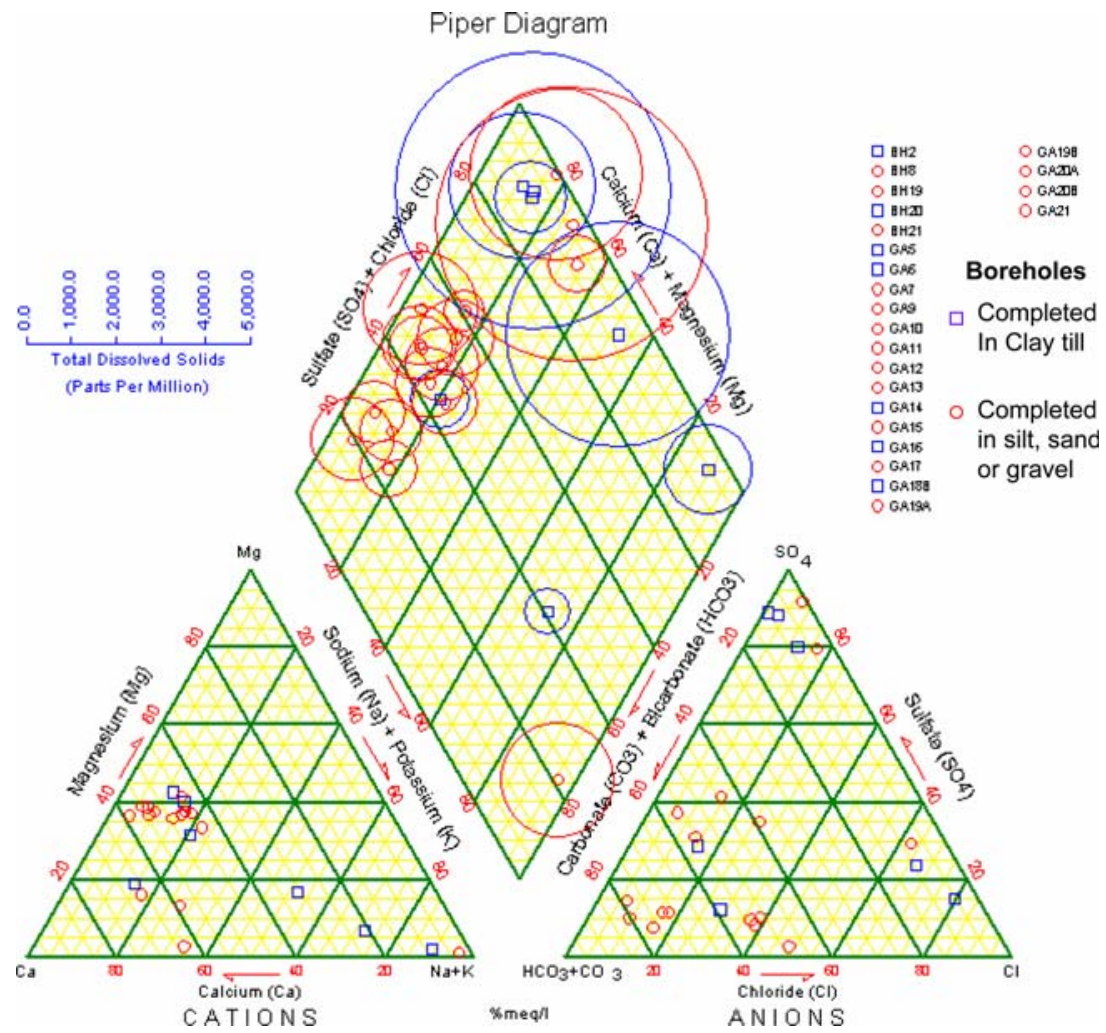

geological material, the surrounding clay till is almost unaffected by the chlorinated solvent contamination, and groundwater from wells screened against the clay till show very low concentrations of VOC.

The TCE concentration distribution also coincides with the permeability distribution in the ECP area. The screened sections of all the boreholes in which elevated levels of TCE and PCE were detected intersect horizons or lenses of coarser materials at $\sim 6 \mathrm{~m}$. Conversely, samples from GA8, GA9 and GA14 which penetrate only the clay till, show low levels of VOCs. Therefore, it appears that groundwater VOC contamination in the ECP area is largely restricted to the lenses of coarser material within the till. The vertical profile in borehole GA19 further indicates that a stiff sandy silt layer between 5.9 and $6.3 \mathrm{~m}$ appears to be retarding the vertical migration of the TCE. Non fractured, water saturated, fine grained media with a hydraulic conductivity of less than $10^{-4} \mathrm{~m} / \mathrm{s}$ will not allow DNAPL penetration (Barbee 1994). Under these conditions it is likely that lateral migration will occur depending on the orientation of its low permeability layer and this may also explain the elevated headspace readings seen at $6 \mathrm{~m}$ in a number of boreholes. Groundwater sampled from below this layer does, however, contain a significant concentration of TCE $\left(22,990 \mu \mathrm{g} \mathrm{L}^{-1}\right)$ in $19 \mathrm{~B}$ indicating that this layer may not be laterally extensive or a complete barrier and may allow TCE to migrate through or around it into the underlying layer.

TCE is present in maximum concentrations at $390,000 \mu \mathrm{g} \mathrm{L}^{-1}$ in GA19A (Table 3). This may be compared to the aqueous solubility of TCE of about $110,000 \mu \mathrm{g} \mathrm{L}^{-1}$. Therefore, TCE is present in the groundwater at in excess of its water solubility, and is therefore inferred to be present in its undissolved state (i.e. as free product) (Drever 1997). Where chlorinated solvents are present in concentrations in excess of $10 \%$ of their water solubility, then the presence of free product NAPL is inferred, as in this case.

The difference in VOC levels between GA3 (outside of the ECP) and BH17 and BH18 may be accounted for by differences in geology, contaminant source or because of containment attenuation. In the vicinity of GA3 in the background area, a 2.5 m thickness of clay and peat underlies $0.76 \mathrm{~m}$ of made ground in which major soil VOC contamination is present. This thickness and the chemical characteristics of clay and peat appear to act as a barrier to downward migration of VOCs. High VOC values in layers $<3.0 \mathrm{~m}$ bgl were highly associated with poorly drained conditions (gleyed) (GA8, GA9, GA10) or peat (GA3). In some instances (GA6, GA12), VOCs are associated with made ground or in GA13 coarse sandy gravel at $<3.0 \mathrm{~m}$ bgl. BH16 also intersects a thick sequence of clay and 
peat below the made ground and the groundwater from GA6 is also uncontaminated. In contrast, BH17 and BH18 have contaminated made ground that directly overlies the clay till, with no clay or peat layers in between to attenuate the VOCs, and significant solvent contamination occurs in the groundwater. Polsen et al. (1998) report that soil types with differing cation exchange capacities and mineralogies affect the vapor sorption and control TCE transport. Clays and material rich in organic matter, such as peat, strongly sorb TCE.

The presence of degradation products indicate active contaminant attenuation and may also contribute to differences in groundwater quality. PCE concentrations are present in $\mathrm{BH} 8$ and $\mathrm{BH} 18$. The $\mathrm{VC}$ is probably a breakdown product of TCE and PCE and its presence indicates some active in situ degradation of chlorinated solvents is occurring in the sediments. Vinyl chloride was found in $\mathrm{BH} 21$ and $\mathrm{BH} 18$. Other studies show similar trends. For example, An et al. (2004) report natural attenuation of TCE by reductive dechlorination produced three dichloroethene (DCE) isomers, vinyl chloride (VC) and ethane in TCE-contaminated sediments on the eastern shores of Lake Michigan, USA.

Boreholes which were sited in areas assumed to represent background conditions show very low VOC levels $\left(<10 \mu \mathrm{g} \mathrm{L}^{-1}\right)$, and, in most cases, they are below the detection limits. The analysis of river water from Kings Court shows that only very low levels of TCE $\left(17 \mu \mathrm{g} \mathrm{L}^{-1}\right)$ and chloroform $\left(9 \mu \mathrm{g} \mathrm{L}^{-1}\right)$ are detected. These compounds may derive from surface water drainage from the Nortel site.

\section{Major ions in groundwater}

Two distinct major ion chemistries occur in groundwater from the site (Fig. 7). Comparison of the groundwater chemistry with the geological material encountered in each borehole shows that the boreholes in clay till have high $\mathrm{Ca} / \mathrm{MgSO}_{4}$ type waters, generally high TSD, low $\mathrm{CO}_{3}$ and often significant $\mathrm{Na}+\mathrm{K}$. The boreholes completed in silt, sand or gravel generally have high $\mathrm{Ca} / \mathrm{MgHCO}_{3} / \mathrm{CO}_{3}$ type waters, high TDS, low $\mathrm{Na}+\mathrm{K}$ and low $\mathrm{SO}_{4}$. Certain boreholes completed in the coarser materials have high $\mathrm{pH}$ and this is associated with high $\mathrm{Na}+\mathrm{K}$ and/or high $\mathrm{Cl}$ levels. With the exception of $\mathrm{BH} 8$, groundwater shows a distinct $\mathrm{CaHCO}_{3} / \mathrm{CO}_{3}$ chemistry, which is more characteristic of the silts and sands than the clay till it penetrates. High groundwater $\mathrm{pH}$ values of 6.4-11.6 suggest derivation from a carbonate rock geology, perhaps dolomite because of high $\mathrm{Ca}$ and $\mathrm{Mg}$ concentrations.
High $\mathrm{Cl}$ levels have been noted in several boreholes which border the road to the east of the ECP. This may be from (1) road salt, (2) dehalogenation of chlorinated organics and (3) higher natural $\mathrm{Cl}$ levels in the small area of the site encompassed by these boreholes. However, the absence of chlorinated organics in GA14 implies that one of the other two mechanisms is more likely.

\section{Conclusions}

The study reveals that the ECP of the Nortel Monkstown Industrial site in Northern Ireland has a complex geological, hydrogeological and chemical regime. However, distinct relationships were determined to exist between the glacial till, the hydrology and the VOCs distribution that aided in the evaluation and design of the intended in-situ reactive barrier. Nevertheless, the low permeable clays with occasional lenses of more permeable sand and gravel from $0.45-7.85 \mathrm{~m}$ bgl complicate the hydrology in the ECP and have major consequences for remedial options in this area. A shallow unconfined aquifer is present within the coarser material. The size and orientation of the sands and gravel lenses control localized groundwater flow and gradient, while steep hydraulic gradients occur at the edges of such lenses making the overall hydrology difficult to interpret. Variations in groundwater major ion chemistry around the site are controlled by the characteristics of the sediments that are penetrated by the boreholes, rather by any site wide trends. Greatest amounts of VOC in groundwater and geological material, mainly TCE, occur at $4.5-7 \mathrm{~m}$ bgl in the coarser material. TCE is also present at elevated levels in $3.0 \mathrm{~m} \mathrm{bgl}$ of the boreholes in zones associated with peat and gleyed poorly drained conditions. The source of the VOC contamination originated near boreholes GA11, BH19 and GA19 in the north-east corner of the site where TCE degreasing activities took place and perhaps leaked into the underlying geological material. Because DNAPL generally migrates vertically and achieves a static spatial distribution in pools within sediments, or in this case coarse lenses, the transport of DNAPL in the ECP area is likely to be controlled by the permeable lenses and fissures in relatively low permeability clay till. The presence of $\mathrm{CDCE}$ and VC (probably breakdown products of TCE and PCE) indicate some active in-situ degradation of chlorinated solvents in the sediments. Vinyl chloride is present in BH21 and BH18.

The upper surface of a thick clayey till, underlying the coarse lenses at about $10 \mathrm{~m} \mathrm{bgl}$, acts as an aquitard 
and is considered to be an effective barrier to the penetration and migration of TCE. Also, its surface is angled to direct any TCE DNAPL in the direction of the reactive barrier. For the reactive barrier, the maximum depth of excavation for the construction of the reactive slurry wall was $10 \mathrm{~m} \mathrm{bgl}$, in order to retain this natural barrier and to avoid creating further downward pathways for contaminant migration.

\section{References}

An Youn-Joo, Kampbell DH, Weaver JW, Wilson JT, Jeong S-W (2004) Natural attenuation of trichloroethene and its degradation products at a lake-shore site. Environ Pollut 130:325-335

Barbee GC (1994) Fate of chlorinated aliphatic hydrocarbons in the vadose zone and groundwater. Ground Water Monit Remediat Winter 129-140

Beck P, Harries N, Sweeney R (2001) Design, installation and performance assessment of a zero valent iron permeable reactive barrier in Monkstown, Northern Ireland. Technology demonstration report: TDP3; Contaminated Land: Applications in Real Environments (Cl:aire), pp 120

Bradford SA, Rathfelder KM, John Lang, Abriola LM (2003) Entrapment and dissolution of DNAPLs in heterogenous porous media. J Contam Hydrol 67:133-157

Broster BE, Pupek DA (2001) The significance of buried landscape in subsurface migration of dense non-aqueous phase liquids: the case of perchloroethyle ne in the Sussex aquifer, New Brunswick. Environ Eng Sci 7:17-29

Drever JI (1997) The geochemistry of natural waters. 3rd edn. Prentice-Hall, Englewood

European Council (1999) Council Directive on the limitations of emission of volatile orgnanic compounds due to the use of organic solvents in certain activities and installations. Official Journal L 085, 29/03/1999, pp 0001-0022

Geological Survey of Northern Ireland (1997) Northern Ireland. Solid geology, 2nd edn. 1:250:000 (Keywort Nottingham; British Geological Survey)

Hvorslev MJ (1951) Time lag and soil permeability in groundwater observations Bull. No. 36, Waterways Exper. Sta. Corps of Engrs, US Army, Vicksburg, Mississippi, pp 1-50

Knight J (2003) Geomorphic and sedimentary evidence for patterns of late Midlandian ice retreat in the Tempo Valley, north central Ireland. Ir Geogr 36:127-144
McCabe AM, Cofaigh CO (1994) Sedimentation in a subglacial lake, Enniskerry, Eastern Ireland. Sediment Geol 91:57-95

Meriano M, Eyles N (2003) Groundwater flow through Pleistocene glacial deposits in the rapidly urbanizing Rouge RiverHighland Creek watershed, City of Scarborough, southern Ontario, Canada. Hydrol J 11:288-303

Methods for the examination of waters and associated materials (1980-1989) Titrimetric determination of total and bicarbonate alkalinity and volitale fatty acids in sewage sludge. Book 44

Morrissey FA, Grismer ME (1999) Kinetics of volatile organic compounds sorption/desorption on clay minerals. J Contam Hydrol 36:291-312

Nilsson B, Sidle RC, Klint KE, Boggild CE, Broholm K (2001) Mass transport and scale-dependent hydraulic tests in a heterogenous glacial till-sandy aquifer system. J Hydrol 243:162-179

Oostrom M, Hofstee C, Walker RC, Dane JH (1999) Movement and remediation of trichloroethylene in a saturated heterogenous porous medium 1. Spill behavior and initial dissolution. J Contam Hydrol 37:159-178

Parker BL, McWhorter DB, Cherry JA (1997) Diffusive loss of non-aqueous phase organic solvents from idealized fracture networks in geologic media. Ground Water 35:1077-1088

Parker BL, Cherry JA, Chapman SW (2004) Field study of TCE diffusion profiles below DNAPL to assess aquitard integrity. J Contam Hydrol 74:197-230

Poulsen TG, Moldrup P, Yamaguchi T, Massmann JW, Hansen JA (1998) VOC vapor sorption in soil: soil type dependent model and implications for vapor extraction. J Environ Eng ASCE 124:146-155

Robins NS (1994) Hydrogeological map of Northern Ireland, 1:250:000 British Geological Survey and Environment Service, Department of the Environment for Northern Ireland

Rockworks (2004) Rockware. V.2004. Earth Science and GIS Software. Golden CO. p 364

Shaw RJ, Hendry MJ (1998) Hydrogeology of a thick clay till and Cretaceous clay sequence, Saskatchwan, Canada. Can Geotech J 35:1041-1052

USDA (2003) Keys to soil taxonomy. 9th edn. USDA-NRCS. $\mathrm{P} 332$

USEPA (2003) Volatile organic compounds in various sample matrices using equilibrium headspace analysis. Method 5021A, p 25

Zhang R, Wood AL, Enfield CG, Jeong S-W (2003) Stochastical analysis of surfactant-enhanced remediation of denser-thanwater nonaqueous phase liquid (DNAPL)-contaminated soils. J Environ Qual 32:957-965 